\title{
THE QUALITY OF LIFE OF THE ELDERLY IN SURAKARTA, CENTRAL JAVA, AND ITS ASSOCIATED BIOPSYCHOSOCIAL FACTORS
}

\author{
Sri Suwarni'), RB. Soemanto²), Aris Sudiyanto3) \\ ${ }^{1)}$ School of Health Polytechnics, Ministry of Health, Surakarta \\ 2)Faculty of Social and Political Sciences, Universitas Sebelas Maret \\ 3)Department of Psychiatry, Faculty of Medicine, Universitas Sebelas Maret
}

\begin{abstract}
Background: The quality of life of the elderly is of major concern in Indonesia and worldwide as the aging population is increasing. Little is known about the association between biopsychosocial factors and the quality of life of the elderly in Indonesia. This study aimed to determine the association between biopsychosocial factors including dementia, family support, peer support, type of residence, marital status, and the quality of life of the elderly in Surakarta, Central Java.

Subjects and Method: This was a cross-sectional study conducted in Surakarta, Central Java. A total sample of 218 elderly people in Surakarta, was selected for this study by fixed exposure sampling, with 1:3 ratio consisting of 50 elderly people living in Dharma Bakti nursing home and 168 elderly people living with their families in the community. The dependent variable was health-related quality of life. The independent variables were dementia, family support, peer support, type of residence, and marital status. The data on the quality of life was measured by WHO-BREF. The data on the other variables were collected by questionnaire. The data were analyzed by path analysis.

Results: Better quality of life of the elderly showed a positive and direct association with strong peer support $(b=0.25, \mathrm{p}<0.001)$, strong family support $(b=0.59, p=0.002)$, mild dementia $(b=1.79, p<0.001)$, and being married $(b=$ 12.73, $\mathrm{p}=0.039)$. Better quality of life showed a positive but indirect association with strong peer support $(b=0.67, p=0.012)$ and living with families $(b=22.93$, $\mathrm{p}<0.001)$, through family support.

Conclusion: Better quality of life of the elderly is directly associated with strong peer support, strong family support, mild dementia, and being married. It is indirectly associated with strong peer support and living with families.
\end{abstract}

Keywords: quality of life, dementia, family support, peer support, elderly Correspondence:

Sri Suwarni. School of Health Polytechnics, Ministry of Health, Surakarta.

Email: tanasfa@gmail.com

Mid-International Conference in Public Health, Best Western Premiere Hotel, Solo, Indonesia, 18-19 April 2018 | 74 https://doi.org/10.26911/mid.icph.2018.01.11 